\title{
Rethinking literary education in the digital age
}

\author{
Alexandra Milyakina \\ Department of Semiotics \\ University of Tartu \\ Jakobi 2, 51005 Tartu, Estonia \\ e-mail:milyakin@ut.ee
}

\begin{abstract}
This paper discusses the perspectives of literary education in the context of the transforming of the notions of literature, reading, and learning. While everyday semiotic practices are becoming increasingly digital and multimodal, school education in most countries is still largely focused on mediating original literary texts in print and their established interpretations. Less conventional sources of literary information brief retellings, comic strips, memes, social media posts - tend to make up a large part of the students' semiotic environment; yet these are usually dismissed by school education as inaccurate and irrelevant. Cultural semiotics, however, allows regarding pulverized versions of texts as a part of a natural educational system - the culture itself. A holistic approach allows not only integrating everyday semiotic practices into a school curriculum, but also revealing the inherent multimodality, transmediality, and creativity of the literary experience. The paper explores possible implications of semiotics in three aspects of literary education: multimodality and heterogeneity of literary experience; influence of digital media on the perception habits; reading as a creative building of a whole from different fragments. The overarching goal is to enrich school education through a deeper understanding of literary experience and a widening of the spectrum of acknowledged tools, formats and media. The theoretical survey is supported by reallife examples from school practice and recreational reading.
\end{abstract}

Keywords: education; literature; cultural autocommunication; digitalization; multimodality

\section{Literary education at school and beyond}

\subsection{The notion of literary synthesis}

In the 1970s, Anton Popovič and Frances M. Macri (1977: 117) regarded literary education as an autonomous semiotic system that "mediates information about original texts to provide contextual information for their reception". According 
to Popovič and Macri (1977: 120), the system of literary education is arranged as follows:

. "Image" of Original: interliterary and intersemiotic translation; summarizing linking (digest, annotation, title); reproductive linking (editorship, document, facsimile, collection, anthology); censorship;

- Interpretation: instruction for reception: literary criticism (including reader's receptive texts); theory; history;

- Literary Advertisement: literary museum; flap, notice, announcement; literary myth (autostylization, biography).

Secondary manipulation of texts included in literary education is, in its turn, represented by literary synthesis: "On its way to a receiver the literary text undergoes various stages of process of literary synthesis, resulting in such syntheses as collections, anthologies, public readings and so on" (Popovič, Macri 1977: 117). This implies a conscious and ideological selection of elements by metacommunicative agents: authors, readers, editors, historians, teachers, etc. In school settings, literary synthesis is present at different levels: firstly, the original text is communicated through educational materials and the teacher's viewpoints; secondly, students create their own syntheses through exercising their personal taste or making cribnotes during exams (Popovič, Macri 1977: 121). Popovič and Macri (1977: 122) consider literary synthesis as a "memory of literature": the image of the original reproduces texts; interpretation "represents the canons of reception and scholarship"; literary synthesis connects literature with a general cultural mythology. Thus, literary synthesis is an expression of cultural and ideological dimensions of literature, strongly affected by such factors as motivation, relation to reality, and relationship to tradition.

\subsection{Literary synthesis at modern school}

Formal education lies at the core of literary synthesis. As a rule, the object and format of learning are subject to regulatory acts issued by the Ministry of Education of the respective state. The following subchapter examines the formal structure of literary education at Russian schools on the basis of governmental regulations. The chosen example is not meant to be universal; however, some of its principles are shared by many educational systems worldwide. Moreover, the educational system in contemporary Russia derives from the former Soviet one, which is also the case in other post-Soviet countries (Froumin, Smolentseva 2014). While education in 
the developed and rather digitized Western world faces similar challenges, this paper discusses the Russian, post-Soviet context, where the digitization gap is even more striking.

The image of the original is largely defined by regulatory acts in Russian schools. There is a strong trend towards creating lists of the approved tools and sources, either traditional, or digital. General educational requirements are listed in the Federal Educational Standard, which is complemented with ministerial orders, recommendations and letters. Literary education in Russia has been traditionally structured around compulsory reading lists that include options. In 2017, the then Ministry of Education and Science of the Russian Federation issued a controversial proposal for the renewed Federal Educational Standard, which included a fixed list of 235 literary works that should be read in five years of general education (Ob utverzhdenii federal'nogo gosudarstvennogo obrazovatel'nogo standarta 2017: $\left.14^{1}\right)$. According to the Ministry, the new standard will allow for the creation of a "united educational space" and eliminate the "excessive variability" of the school programme, in contrast to the more flexible current version. Even though the teachers' communities strongly oppose this idea, some experts, parents, and educators welcome it as a continuation of a long-standing Soviet-Russian tradition. The means of literary education - that mostly deal with interpretation and partly with literary advertisement - are also subject to regulation. According to the list of educational and upbringing means, these include educational materials (textbooks, study plans, anthologies, tests, activity books, etc), educational films, tables, portraits of writers and literary scholars, pictorial reproductions, reference books, encyclopedias, computers and software (Ob utverzhdenii perechnya sredstv 2016: $12^{2}$ ).

According to official documents, the main goal of literary education is defined as "the development of the culture of reading and the achievement of reader's independence based on the skills of analysis and interpretations of literary texts"

1 Ob utverzhdenii federal'nogo gosudarstvennogo obrazovatel'nogo standarta osnovnogo obshchego obrazovaniya v novoj redaktsii: proekt prikaza Minobrnauki RF ot 09.07.2017. [O6 утверждении федерального государственного образовательного стандарта основного общего образования в новой редакиии: проект приказа Минобрнауки РФ от 09.07.2017.] Retrieved from http://www.garant.ru/products/ipo/prime/doc/56619643/ on 24 September 2018.

2 Ob utverzhdenii perechnya sredstv obucheniya i vospitaniya [...]: prikaz Minobrnauki RF ot 30.03.2016. № 336. [Об утверждении перечня средств обучения и воспитания [...]: приказ Минобрнауки РФ от 30.03.2016. № 336.] Retrieved from http://www.garant.ru/ products/ipo/prime/doc/71274142/ on 24 September 2018. 
(Primernaya osnovnaya obrazovatel'naya programma 2015: $31^{3}$ ). One of the tasks is to "teach the language of culture" and to support the cultural integration of the learner (Metodicheskie rekomendatsii 2017: $6^{4}$ ). In practice, the reader's motivation is too low, and the stage of reading the original text is often omitted from the school practice, especially in senior classes (Kontseptsiya prepodavaniya 2016: $\left.4-5^{5}\right)$. As a result, many students do not develop any interest in acquainting themselves with the enormous body of Russian and world literature. The situation is not unique but exemplifies the global problem, when the growing size of the cultural heritage is "more and more in conflict with students' capacity to assimilate knowledge" (Marcus 2015: 72). The educational system evidently disregards the idea of cultural autocommunication, which implies that culture is not contained in "approved lists", but is based "both on inner dialogue as well as on dialogue with the surrounding world" (Ojamaa, Torop 2015: 70). The abovementioned official documents describe unconventional literary sources as invalid and harmful. For instance, the students' interest in short summaries is associated with superficial understanding of literature and poor results in the exams; teachers are warned that summaries can provide only a very general overview of the text or even distort the perception (Kontseptsiya prepodavaniya 2016: 5). The goal of literary education would seem impossible, if the notions of 'culture of reading', 'reader', and 'literary texts' could be defined only in a narrow sense.

3 Primernaya osnovnaya obrazovatel'naya programma osnovnogo obshchego obrazovaniya: odobrena resheniem federal'nogo uchebno-metodicheskogo ob'edineniya po obshchemu obrazovaniyu ot 08.04.2015. № 1/15. [Примерная основная образовательная программа основного общего образования: одобрена решением федерального учебно-методчческого объединения по общему образованию от 08.04.2015. № 1/15.] Retrieved from https:// минобрнауки.рф/проекты/413/файл/4587/POOP_OOO_reestr_2015_01.doc on 24 September 2018.

4 Metodicheskie rekomendatsii po prepodavaniyu russkogo yazyka i literatury v 2017-2018 godu: utverzhdeny Upravleniem obrazovaniya i molodezhnoj politiki Administratsii goroda Ryazani ot 03.04.2017. № 04/1-10-1813. [Методические рекомендации по преподаванию русского языка и литературы в 2017-2018 году: утверждены Управлением образования и молодежной политики Администрации города Рязани от 03.04.2017. № 04/1-10-1813]. Retrieved from http://ecole6.my1.ru/metod_rabota/mr_russkij_jazyk_literatura_17-18.pdf on 24 September 2018.

5 Kontseptsiya prepodavaniya russkogo yazyka i literatury v obshcheobrazovatel'nyh organizatsiyah Rossijskoj Federatsii: utverzhdena rasporyazheniem Pravitel'stva Rossijskoj Federatsii ot 09.04.2016. № 637-r. [Концепизия преподавания русского языка и литературы в общеобразовательных организациях Российской Федерации: утверждена распоряжением Правительства Российской Федерации от 09.04.2016. № 637-p]. Retrieved from http:// static.government.ru/media/files/GG2TF4pq6RkGAtAIJKHYKTXDmFlMAAOd.pdf on 24 September 2018. 


\subsection{Literary synthesis in culture}

Literary synthesis is a part of literary education (Popovič, Macri 1977: 122), and, certainly, not all literary education is limited to school. Formal education is largely based on a conventional content-delivery system, with a teacher (or educational content provided by the teacher) playing the leading role. In these transmission classrooms, "ready-made meanings are supplied with the expectation that they be reproduced at a later time as an indication of learning" (Siegel 1995: 464). However, crucial processes of literary education are also taking place beyond the school walls. I propose analysing this process in view of Juri Lotman's notion of cultural education (Lotman 2000).

Lotman regards culture as a language and a totality of texts in this language (Lotman 2000: 417). The function of cultural education consists in a transmission of nonhereditary information to individuals and collectives. Two methods of education are associated with different structures of cultural code: some cultures are oriented towards texts and precedents, whereas others are seen as sums of norms and rules. Cultures of the former type do not include a meta-level that describes the laws of its creation; cultures of the latter type value rules more than texts. Interestingly, the culture itself and its self-models can be created under contradicting principles: Lotman gives the example of Peter the Great's state that presented itself as rule-based as opposed to a chaotic - text-based - everyday life. Imposing rules top-down does not mean that a culture would necessarily restructure itself in accordance with the new rules, even though it can sometimes cause a turn in cultural evolution. The abundance of rules interferes with the effective perception, conservation and creation of information (Lotman 2000: 424).

Accordingly, each culture can generate different and sometimes opposite understandings of literature: the oscillation between these understandings ensures the informational capacity of the system (Lotman 1992a: 209). For instance, culture can regard mass literature as the most widespread, popular and readable, and, at the same time, totally dismiss it (Lotman 1992a: 212). The gap between the everyday literary experiences of students and school practice can be explained by a contradiction between culture itself and its self-model - an "ideal" school system described by regulatory acts. This gap can be bridged by teachers and enthusiasts, those situated beyond the school walls, such as, for example, IT-developers, who can integrate new texts and activities into a school practice. Due to them, literary synthesis at school includes not only compulsory works and their official interpretation, but also texts that exist beyond the standard and play an important role in the everyday life of students. 


\subsection{Challenges to literary education}

The development of digital technology has boosted the generation of new literary texts and retellings of old stories. Many of those texts are seemingly different from paper-based books: they are not only verbal, but also visual and audial; they can exist as full-sized versions or be pulverized into anonymous pieces; they can modify the original story in different ways and allow the reader to choose. The commonsense definitions of 'text', 'book' and 'reading' are undermined by laws of the new media landscape where texts are bound by hyperlinks and presented non-linearly (Manovich 2001: 77). Text is no longer "the written words in a book, magazine, etc., not the pictures"; book is not only "a set of pages that have been fastened together inside a cover to be read or written in"; to read requires much more than just "to look at words or symbols and understand what they mean" as the definitions from Cambridge Advanced Learner's Dictionary would tell us.

In order to catch up with the dynamically evolving textual culture, formal literary education has to revise its own foundations. On the one hand, school curriculum is overstuffed with compulsory literary works; on the other hand, it includes only few types of texts that are actually involved in cultural autocommunication. Literary education faces a double challenge: "[...] the specific nature of literary discourse should be kept clear, and at the same time the overall media landscape and the sprawl of media forms, old and new, should be acknowledged, with literary discourse seen as an inseparable part of this larger field" (Koskimaa 2007: 182). The prevailing notion of literacy should be expanded by multimodal literacies reflecting the semiotic systems that young people use (Jewitt 2006: 330). One of the solutions would be to explore the ways in which students - consciously or unconsciously - educate themselves beyond the school walls: how they read and write; how they share, perceive and create literaturerelated information. Indeed, the integration of those texts and practices into a school curriculum might appear challenging, since it deals with the problems of multimodality, digital media, and faithfulness to the source. A semiotic perspective offers insight into how to establish a continuity between older and newer forms of literature. By taking a closer look at the nature of the literary text, it is possible to see how some "inconvenient" or "improper" features are inherent to any artistic text in general. Rather than disregarding multimodal, digital, or unfaithful adaptations (transductions) as irrelevant, literary education can reclaim those texts and adapt them to classroom settings. 


\section{Multimodality of reading}

\subsection{The origin of multimodality studies}

Multimodality is a concept from which an interdisciplinary approach stems, which focuses on multiple modes used in human communication and expression. Even though the idea of multimodality has been studied long before the 21th century, it has become fully actualized only recently in the works of Gunther Kress, Theo van Leeuwen, Carey Jewitt and other scholars. 'Mode' is defined as "a socially and culturally shaped resource for making meaning", such as image, writing, layout, speech or moving images (Kress 2010: 79). According to the multimodal approach, "meanings are made (as well as distributed, interpreted, and remade) through many representational and communicational resources, of which language is but one" (Jewitt 2008: 246).

Different modes are to some extent present even in texts that are generally considered monomodal - for instance, literary works printed on paper without any illustrations. Human perception of the world is inherently multimodal, and representations "exist in a continuous flow of shifting relationships" (Fleckenstein 1996: 917): attributes of visual images are used for categorization in the verbal mode, while the verbal text evokes images. From the perspective of Lotman's semiotics, every artistic text exists in a relation to different sign systems and possesses a certain correlation between word and picture, narrative and performance (Lotman 1992c: 36). Verbal-linear and iconic-spatial languages of culture are regarded as complementary: the perception of a written narrative is inseparable from the mental construction of images - visual, audible, and even olfactory and tactile. Starting from Aristotles' Poetics, the interrelation of different sign systems in art has been an object of a vast theoretical discussion; for instance, the visual aspects of the Russian literary narrative were thoroughly explored in the collection edited by Anderson and Debreczeny (1994). While the 20th century was characterized by a florescence of mixed genres, the prose of some earlier writers, such as Tolstoy or Chekhov, shows a strong link between word and image: "We explore whole scenes by "seeing" them rather than "hearing" their explanation" (Anderson, Debreczeny 1994: 4).

Any act of human communication should be considered as multimodal, since it cannot entirely make an abstraction of all other available modes of representation apart from verbal language. Alongside Kress and van Leeuwen's study of the role of images (Kress, Van Leeuwen 2006[1996]), other works focus on the role of paratextual and nontextual factors and explore such semiotic resources as sounds, movements, gesture and spatiality (Leeuwen 1999; Kenner 2004). Each of the modes plays a discrete role in a communicative act and "provides specific potentials and limitations for communication” (Kress 2005: 5). 


\subsection{Multimodality in the digital age}

Digital technology evokes the problem of multimodality at a new level, since it allows integrating almost unlimited amounts of verbal, audiovisual, or even sensory information. Literary texts are retold and enhanced in different ways: from the simplest e-books to game-like virtual environments. However, the opportunity to augment reading with other modes is undermined by the risk of "impoverishment, distraction, contamination" (Toolan 2010: XVIII). The ratio of different modes in communication can be measured from the perspective of underdetermination and overdetermination. The situation of underdetermination is associated with the lack of available codes and "entails the necessity for readers to supplement the text with their own interpretations" (Tymoczko 2014: 200). Overdetermination, in its turn, works for the benefit of clarity and implies that the reader's interpretative power is shifted onto many codes. The confrontation of these two approaches is reflected, for example, in a longstanding discussion about whether the visual language is more concrete than the verbal one.

For instance, Lamb (2011: 17) argues that "over-reliance on audio, bells-andwhistles features that distract readers, and "eye candy" unrelated to the story can divert attention, cause readers to lose focus, and adversely affect learning". The current argument on the roles of different modes in reading echoes the old debate on the "desirability of reading the bare text or of reading the text heavily annotated and supplemented by critical exegesis and commentary, intratextual and intertexual reference, and a record of all invariant textual forms" (Toolan 2010: XVIII). Also, it can be linked to a longtime discussion around the role of the illustrations in books.

Multimodality is even more explicit in the new forms of literature. For instance, augmented reality books make use of both virtual and physical worlds: it is possible to perceive the original text in a written form and augment the experience with games and entertaining activities in a virtual environment. Researchers at MIT Media Lab went even further and developed an immersive tool for triggering certain emotions or physical states (Heibeck et al. 2014). Whereas traditional fiction creates emotions through words, Sensory Fiction portrays the scenery and sets the mood through a combination of sensors and actuators. By means of the light, sound, heat, vibration and compression, the (non-fictional) reader can experience changes in the (fictional) protagonist's state. The developers believe the tool still allows space for the creative activity of the reader's imagination. Even though Sensory Fiction is only a prototype and the idea has not been scientifically tested, the project poses interesting question for the future of storytelling. 


\subsection{Educational implications}

The logocentric ideology promoted in schools "has led us to regard language as the sole channel for learning and to separate it from other ways of knowing" (Siegel 1995: 456). In the perspective of multimodality, the hierarchy of modes is correlated with social and cultural values. Thus, a large amount of linear handwriting or printed text implies the valuing of specialist knowledge, authority, and authenticity (Jewitt 2006: 323). According to Kress (2004: 18), traditional print (and handwriting) will continue to exist, since "the elites will continue to use writing as their preferred mode, and hence, the page in its traditional form". However, the visual turn has already affected even the most conservative fields of education, such as scholarly work: in 2015, Columbia University awarded a doctorate degree to Nick Sousanis for Unflattening, a thesis in the form of a graphic novel (Sousanis 2015).

In schools, a shift can be noticed "from the dominance of writing as the main or at times sole carrier of meaning to an increasing reliance on image" (Kress 2010: 46). Recently the demand for multimodal pedagogy has been acknowledged by educational systems around the world, including Finland, Australia, Scotland and other countries (Chandler 2017: 2). At the same time, the increasingly larger role of different modes is often anticipated with pessimism and distrust. Multimodality delivers agency to the students in meaning-making processes and multiplies channels of information: attention is not predefined by metacommunicative agents but shaped as a result of student's attention. While the multimodal design offers different points of entry into a text, it is the task of the reader to find and create a reading path: for instance, it is possible to get acquainted with the metatexts prior to reading the original text itself, or dwell on visual representations of the story instead of reading the words. In this case, the process of internalization takes place as follows: "[...] interest shapes attention, which produces engagement leading to selection of elements from the message, leading to a framing of these elements, which leads to their transformation and transduction, which produces a new ('inner') sign" (Kress 2010: 42).

The main problem is whether literary education can afford to shift away from logocentric ideology. For the time being, the ability to read a verbal text is considered a crucial skill for a contemporary student; however, it is not clear to what extent literary education must be based on the reading of monomodal linear texts (in the classic sense), if some of its aims can be as well reached without it. The shift from a logocentric model implies that a reader needs to learn how to correlate different sign systems and generate meaning (Siegel 1995: 464). The hierarchy of different modes in literary education needs to become a key question in further 
pedagogical discussions. Among other issues, it is important to study how different modes are involved in the building of reading experiences and what are the risks and perspectives of integrating new ones.

\section{From paper-based books to digital universes}

\subsection{The role of the medium}

Each literary work is, firstly, realized by means of verbal language, and, secondly, through a certain medium. According to Juri Lotman (1998: 24), the dualism of form and content should be replaced by a concept of idea which is reflected in an adequate structure in a way which supposes the impossibility of it surpassing the structure. At the same time, the literary text is inseparable from its medium, be that of a paper-based book, an e-book, or a literary video game. All those images of text, handwritten, typed or represented in other sign systems, could be considered text models (Buzzetti et al. 2002: 61). In contrast to new media, traditionally, paper-based books are conventionally regarded as neutral and transparent media for literary texts. However, paper-based books possesses formal properties that strongly influence the reading experience as well, often without the reader noticing (Hayles 2000: 94).

The concept of medium specificity implies that the properties of the artistic work are rooted in the materiality of the medium (Greenberg 1960). The development of digital technology and, consequently, of such technology's specific media made explicit the materiality of literature, which has always been a major component in the experience of reading. The "thingness of the book" is how James Monaco describes the physical dimension of a paper-based book - its unique weight, feel, and smell (Monaco 2000: 15). The medium of a book has many features that are usually taken for granted: starting from the feel of holding the book in one's hand, to the appearance of the page, and to the different paratexts, such as titles, covers, blurbs and introductions (Mackey 2001: 169-170). Paperbased book, as a conventional model of the literary text, has been formed under the influence of cultural, historical and social circumstances. On the one hand, it reflects the long-standing ideas of authorship and authenticity of the text; on the other hand, it represents reading as a private and solitary activity. Digital texts and oral storytelling, however, are concerned with these issues to a lesser extent.

While keeping in mind the specificity of each medium, it is important to focus on the continuity between newer and older media. As claimed by Lev Manovich (2001: 65), "new media is an old media which has been digitized". Interestingly, this is rarely recognized by the developers of digital books, who claim that their 
products "reinvent reading" or have nothing to do with "traditional books". In truth, most of the so-called innovations in the field of digital literature were tested a long time ago in pre-digital experimentations. For instance, augmented reality projects inherit their features from paper-based books with maps; multimedia e-books with pictures and sounds have much in common with colorful popup books; the possibility of interactive literature was explored by the authors of experimental fiction (such as Julio Cortázar's novel Hopscotch). Bolter and Grusin (2000: 45) distinguish four ways "in which digital media remediate their predecessors", namely duplication, enhancement, refashioning, and absorption.

\subsection{Challenges of the digital technology}

Digitization implies much more than just converting information into bits and presents challenges that could not have been imagined earlier. According to Lev Manovich (2001: 49), new media are characterized by the digital distribution of knowledge, software control of data, mix of the older and newer cultural conventions, faster execution of algorithms, use of metamedia, and new aesthetics. Other features of digital media include reactive and interactive nature, performativity, use of multiple sensory and semiotic channels, networking capabilities, volatility, and modularity (Ryan 2004). While being intrinsically neutral, these characteristics could be both beneficial as well as harmful to reading.

On the one hand, digital technology provides powerful possibilities for readers and researchers, since it helps to overcome the spatial limitations of paper-based editions. Among other things, it allows to integrate texts with different media and teaching materials; brings together dispersed collections; enhances searchability; displays in operational formats materials in otherwise inaccessible formats, such as large volumes or maps (Deegan, Tanner 2004: 489). The digital medium can increase the transparency of the reading process: for instance, it is possible to look up a word in a built-in dictionary without interfering the flow (Mackey 2001: 100). Also, readers are offered the possibility to choose between different authorial variants or new and old spelling versions (Schreibman 2002: 292). On the other hand, some features of the digital medium can cause attention and comprehension problems, even to the point of affecting one's health. In 2014, a study found that Kindle users were less competent in remembering the plot and events of a narrative. This is connected to the inability to physically and visually track the progress (Mangen et al. 2013: 61). Also, scrolling was claimed to cause "a spatial instability which may negatively affect the reader's mental representation of the text" (Mangen et al. 2013: 65). The Internet presents additional problems, as it "encourages the creation of texts that consist entirely of pointers to other texts 
that are already on the Web" (Manovich 2001: 127). Consequently, texts become more fragmented and can include multiple links to different places on the Internet.

In a constant quest for readers' attention, books compete not only with the social media, games or TV, but also with different versions of the original text audiovisual adaptations, summaries, retellings, reviews and digital editions. Continuous recursion and compression of information in the digital age are described by the notion of nanotextology (Hampson 2007). Literary texts are inseparable from a large surrounding apparatus that includes the materials offered by authors and distributors (advertising materials, satellite texts) as well as the products of readers' reception (summaries, book trailers, comics strips, memes, posts on social media). It is possible to get acquainted with Hamlet without even reading the original play by Shakespeare. However, nanotextology is yet an underresearched field: it is not clear whether potential readers are actually directed to the book by nanotexts; also, there is little evidence on how the quantity of literary exposures transforms into quality.

\subsection{Educational implications}

Whereas schooling is preoccupied with reading classic literature, the everyday semiotic environment of students requires skills for comprehending other types of texts. On the basis of 46 studies reviewed by Afflerbach and Cho, strategies used for reading digital texts "appear to have no counterpart in traditional reading" (Afflerbach, Cho 2010: 217). The amount, volume and structure of texts have changed drastically. While the next generation of children and young adults is getting used to interacting with the new types of information, they often struggle to perceive traditional linear fiction (Kontseptsiya prepodavaniya 2016: 5). Indeed, a print text requires more attention than other media and "involves a deliberate disruption to the forms of naturally evolving flow" (Mackey 2002: 11). As a result, students engage in "simulative reading activities" - which is an official description for reading short summaries or using ready-made essays (Kontseptsiya prepodavaniya 2016: 5). This quote from the "Project for teaching Russian language and literature in general education" implies a division in oppositional value terms of "true" and "simulative" reading. Thus, literary education values only a certain type of expertise, while the students' experience in dealing with non-linear, digital and multimedia texts is often disregarded as invalid or even harmful.

Reading paper-based books could be no longer considered a superior way of perceiving literature; rather, it should be conceptualized as a part of media ecology. In 2009, the International Reading Association emphasized the importance of 
integrating information and communication technologies into current literacy programmes (Lamb 2011: 15). Digital learning materials are being actively used in literature classes in the USA, Scandinavia, East Asia and other regions. While the initial remarks about the mediatic conservatism of post-Soviet education stand, even Russian official documents admit that, "from their childhood, modern learners deal with large amounts of digital texts [...] which should not be ignored by the school system" (Kontseptsiya prepodavaniya 2016: 8). The shift from older to newer forms of reading would require the revision of what is meant by being 'literate' or a 'good reader' (Hunt 2000: 111). Traditionally, stories progress through narrative units united by "character, scene, atmosphere, theme or motif" (Hunt 2000: 114). In the digital world, stories do not necessarily live by these rules and require a creative selection and organization of the elements (Hunt 2000: 114). The result of this creative work is highly personal, inaccessible to evaluation and even unrecognizable as a narrative. To some extent, traditional reading has always been based on the same premises, but "it would not be in the interests of the critical/ educational establishment at any level to admit it" (Hunt 2000: 117).

\section{Reading as playing}

\subsection{Reading as a creative process}

Exploring transmedia universes or hypertext fiction might seem very different from turning the pages of a book. However, the creativity and unpredictability of reading has been inherent to the traditional literature as well. Digital technology only intensifies literary features as theorized by Bakhtin or Derrida - "the reconfiguration of the author, non-linear narrative, and the democratization of control over the text" (Rockwell 2002: 352). From Lotman's perspective, text is not a mere manifestation of a message in some language, but a complex mechanism that contains different codes, transforms the received messages and generates new ones (Lotman 1992b: 132). Lotman (1992b: 130) distinguished between five socio-communicative functions of text: (1) communication between the sender and receiver; (2) communication between the readers and the cultural tradition; (3) communication of readers with themselves; (4) communication of the readers with the text; (5) communication between a text and the cultural context.

Rather than just decoding the text, the reader is involved in a meaningful interaction with the text, which is a very sophisticated and unique process. Communicative functions of the text are essential to the idea of transmediality. According to Lotman (2001: 143), the "elementary act of thinking is translation", which can be understood as a translation into another system of signs. Since the 
translation "always includes a certain element of untranslatability" (Lotman et al. 1973: 15), every interaction with the text is creative. This comes in line with Barthes's idea of reading as playing, when "the text itself plays (like a door, like a machine with 'play') and the reader plays twice over, playing the Text as one plays a game" (Barthes 1986[1971]: 62). Active reading is associated with "writerly texts", which require that readers introduce their own codes to interpret and rewrite the text - in contrast to "readerly texts" that are perceived passively and offer mere pleasure (Barthes 1975: 14).

To widen the connotations of reading, Mackey also uses the term "playing the text", which for her entails pretending, performing, engaging with the rules of the game, strategizing, orchestrating, interpreting, fooling around and not working (Mackey 2002: 181). To consider reading as solely text-oriented is to underestimate the creative force of reading (Mackey 2002: 165). Factors that influence the reading process are not only text-based, but also readerbased and situational - they include gender, race, education, social class, age, reading habits (Warwick 2004). In the age of the Internet and artificial intelligence, those factors interplay and multiply at an exponential rate.

\subsection{Reading as playing in the digital world}

In the digital world, reading often entails processing of information through various media, taking active decisions on the development of the plot, and collectively interpreting the text. Playing with the text can imply different levels of participation and intervention: from adding comments to rewriting the story from scratch. The process of reading in the digital world reflects the correlation of different languages in culture. Being a naturally semiotic phenomenon, it consists in establishing the links between texts in different cultural languages. The structure of digital reading can also reflect the evolving hierarchy of cultural languages - the importance and amount of words, images, sounds and other semiotic resources.

In contrast to paper-based editions, digital environments allow not only reading the text privately, but also sharing opinions and interpretations in real time and preserving them for future readers. As a result, "present-day readers overhear the dialogue created between past readers and the text" (Schreibman 2002: 290). The classic idea of a book club has been realized on a large scale with the help of online platforms - often with the participation of the authors. Literary fans crowdsource annotations on popular sites like Genius; participate in special projects such as Infinite Ulysses; begin conversations right in the middle of pages via educational tools Subtext or SocialBook. Readers can step beyond the individual experience and create shared literary-related spaces on the Internet - such as fan fiction sites or "story palaces" (Unsworth 2006: 40). 
Readers' participation in the text can also be predesigned, and not only spontaneous. The experiments with chatbot fiction and artificial intelligence were foreseen by many 20th-century authors, such as, for example, Marc Saporta, whose Composition No. 1 consists of 150 unbound pages. Through physically chunking and rearranging the text, authors were "making the text endlessly selfrenewable" and "turning the work of art from a static self-identical object into a matrix of virtualities" (Ryan 2004: 418). Digital technology offers powerful tools for creating multi-variant narratives with the possibility to change the plot and the perspective of the discourse. Lowest degree of interactivity is exemplified by interactive fiction, which allows the reader to determine the outcome of the narrative through choosing the options. For instance, Inkle's interactive adaptation of Jules Verne's Around the World in Eighty Days allows modifying the route of Phileas Fogg's journey. Tools powered by artificial intelligence can help "to maintain a more human-like feedback loop with the reader" (Winder 2004) - such as the Versu mobile app that models dialogues with literary characters. In contrast to more logocentric examples of interactive fiction, video games provide a cinematic representation of the story. The user may acquire a first-person perspective of the scene, which creates an effect of immersion: being able to directly control the point of view, "the player is often both actor and director" (Bolter, Grusin 2000: 47). Some sophisticated games go even further and abandon the original narrative altogether. Instead of following the plot, players are enacting their own stories in the virtual world of the video game. According to Mackey (1999: 27) such games reflect children's "life-long exposure to a culture full of many different kinds of [alternative narratives]".

\subsection{Educational implications}

Books no longer represent "the end of the story" and are going to survive only as "part of a "both/and" world where they belong to a more general world of texts" (Mackey 2001: 169; 179). According to Unsworth (2009: 37), "these expanded dimensions of the experience of story are a significant part of what encourages many young readers to maintain their engagement with extended and intensive reading of books in multimedia world".

In order for literary education to reflect the reading experience as a contemporary cultural phenomenon, it has to reconsider the primacy of the linear narratives and paper-based books. To "liberate" digital narratives "from the shadow of the novel", it is necessary to abandon the idea of the novel and instead play in the phase space surrounding storytelling (Weldon 2012: 64). Reading in the age of the Internet "may seem to be no more nor less than individual, unassessable chaos" (Hunt 2000: 111). The pedagogic framework proposed by Len Unsworth (2006) 
allows integrating student-centred and discovery learning into school practice. For instance, students can begin the work on the topic by sharing informal knowledge, while the teacher will "bridge towards negotiating more systematic knowledge" and thus set the stage for collaborative group work and independent research (Unsworth 2006: 7-8). Interaction with new types of literary texts and paratexts can provoke discussion on the constructedness of the story and the modelling capacities of different media (Unsworth 2006: 7-8).

\section{Literary education redefined}

Arguably, "if a certain kind of text/culture is supported in school but not elsewhere, then its study will probably be counter-productive" (Hunt 2000: 113). A considerable decline in reading motivation should be explained not by the laziness or ignorance of students, but by a tectonic shift in the cultural landscape. Beyond the school walls, the understanding of literature has already changed and now embraces a wide range of forms, including texts in other media: from video games that are often labelled as "interactive books" to film adaptations positioned as "literature on screen" both by creators and promoters. As claimed by Hunt (2000: 113), "if the hand-held book is identified with school (especially if is identified with some vague 'literary' value), then other media will continue to dominate". The challenges posed by the digital age are not totally new. On the contrary, they were pre-defined by the nature of the artistic text as such. Instead of discriminating against digital and multimodal texts on the basis of their unfamiliarity alone, literary education needs to face the problem and adapt to the new circumstances.

A promising answer to these challenges is given by the above-mentioned Australian curriculum, which not only includes texts "identified as 'literary' across a range of media and forms", but also encourages students to "interpret, appreciate, evaluate and create literary texts in many forms and modes" (Beavis 2013: 242). In the curriculum, the term 'literary' is associated with the ideas of 'aesthetic' and 'appreciation', which allows thinking about literature without "referring exclusively to the heavyweight high-culture texts of the English tradition" (Beavis 2013: 243). According to Beavis, the introduction of these associations "opens up the invitation to work with a wide range of modes and text-types", as well as "opens up the possibility of broadening the texts and modes that might be considered literary and aesthetic" (Beavis 2013: 243). While the traditional forms of literary texts are deemed important, the curriculum also recognizes the diversity of children's literary experience. As a result, the understanding of aesthetic (and literary) texts is expanded by including video games, graphic novels, and other multimodal texts. 
While many questions related to the interpretation and implementation of the curriculum remain, teachers and students are given space for making their own choices.

The freedom of choice is what is considered the most important right by the Russian pedagogical community, which is currently struggling with the harsh legislation. In a protest against the renewed Federal Educational Standard, the Guild of Language and Literature Teachers issued an open letter listing the fallacies of the project (Otkrytoe pis'mo $2018^{6}$ ). The authors consider the standard as a serious setback for literary education, since it ignores the interests and capacities of teachers and students, disregards the changing reading practices, and does not face the modern challenges. The standard neither includes texts that are popular among students nor promotes skills other than reproduction of ready-made knowledge. As stated in the letter, the proposed strategy suppresses the motivation of the students and can eventually cause a situation, in which young people would never start reading. In return, the Guild puts forward a modern pedagogy-driven approach requiring that students develop independent and critical thinking, as well as the skills of creative and explorative learning.

Summing up, the main role of literary education should be therefore to guide students in the world of versions and retellings. Rather than simply mastering reading skills, students need to acquire the competencies appropriate for contemporary communication. At the same time, education should facilitate the comprehension of cultural heritage (Ojamaa 2015: 35), which should not be imposed on the future generations, but "should be negotiated, explained and modified accordingly" (Marcus 2015: 83). Instead of being fixed by legislation acts, the representation of the cultural heritage must be "critical, selective, integrative, flexible and dynamic" (Marcus 2015: 74). Firstly, a shift from a logocentric to a multimodal model would require an understanding of the specificity of the verbal medium instead of blind enforcement of its primacy. Secondly, the inevitable usage of digital sources in literary education should be supported by recommendations on how to use these short, multimodal and often anonymous versions. Thirdly, any interpretation of a literary work should be based on a play and exploration rather than on instruction. From the perspective of cultural semiotics, "any text may exist in a series of possible forms and interpretations, none of which is the ultimate or ideal one" (Ojamaa; Torop 2015: 64). Only when the literary education admits

6 Otkrytoe pis'mo uchitelej literatury, metodistov, vuzovskih prepodavatelej. Gil'diya Slovesnikov, 2018. [Открытое письмо учителей литературы, методистов, вузовских преподавателей. Гильдия Словесников, 2018]. Retrieved from https://slovesnik.org/novosti/otkrytoepismo-uchitelej-literatury-metodistov-vuzovskikh-prepodavatelej.html\#hcq=y5aLIMq on 24 September 2018, 
this fact, it can deal with the real challenges: define the specificity of the verbal medium; develop strategies for controlling the chaos and transforming the quantity into quality; finding out what is the core of the text and how it is changed in a play.

\section{References}

Afflerbach, Peter; Cho, Byeong-Young 2010. Determining and describing reading strategies: Internet and traditional forms of reading. In: Waters, Harriet Salatas; Schneider, Wolfgang (eds.), Metacognition, Strategy Use, and Instruction. New York: Guilford, 201-225.

Anderson, Roger; Debreczeny, Paul (eds.) 1994. Russian Narrative and Visual Art: Varieties of Seeing. Gainesville: University Press of Florida.

Barthes, Roland 1975. The Pleasure of the Text. (Miller, Richard, trans.) New York: Hill and Wang.

- 1986[1971] From work to text. In: The Rustle of Language. (Howard, Richard, trans.) New York: Hill and Wang, 56-68.

Beavis, Catherine 2013. Literary English and the challenge of multimodality. Changing English 20(3): 241-252.

Bolter, Jay David; Grusin, Richard 2000. Remediation: Understanding New Media. Massachusetts: MIT Press.

Buzzetti, Dino 2002. Digital representation and the text model. (Morris, Jon; Morris, Marella, trans.) New Literary History 33(1): 61-88.

Chandler, Paul D. 2017. To what extent are teachers well prepared to teach multimodal authoring? Cogent Education 4(1): 1-19.

Deegan, Marilyn; Tanner, Simon 2004. Conversion of primary sources. In: Schreibman, Susan; Siemens, Ray; Unsworth, John (eds.), A Companion to Digital Humanities. Oxford: Blackwell, 488-504.

Fleckenstein, Kristie S. 1996. Images, words, and narrative epistemology. College English 58 (8): 914-933.

Froumin, Isak; Smolentseva, Anna 2014. Issues of transformation in post-socialist higher education systems. European Journal of Higher Education 4(3): 205-208.

Greenberg, Clement 1960. Modernist painting. Forum Lectures. Washington, D. C.: Voice of America, 193-201.

Hampson, Gary P. 2007. Integral re-views Postmodernism: The way out is through (As key fragments). Integral Review 4: 108-173.

Hayles, N. Katherine 2000. The condition of virtuality. In: Lunenfeld, Peter (ed.), The Digital Dialectic: New Essays on New Media. Cambridge: MIT Press, 68-96.

Heibeck, Felix; Hope, Alexis; Legault, Julie 2014. Sensory Fiction: A design fiction of emotional computation. Proceedings of the 2nd ACM International Workshop on Immersive Media Experiences. New York: ACM, 35-40.

Hunt, Peter 2000. Futures for children's literature: Evolution or radical break. Cambridge Journal of Education 30(1): 111-119.

Jewitt, Carey 2006. Multimodality, "reading", and "writing" for the 21st century. Discourse: Studies in the Cultural Politics of Education 26(3): 315-331. 
- 2008. Multimodality and literacy in school classrooms. Review of Research in Education 32: 241-267.

Kenner, Charmian 2004. Becoming Biliterate: Young Children Learning Different Writing Systems. Stoke-on-Trent: Trentham.

Koskimaa, Raine 2007. Cybertext challenge: Teaching literature in the digital world. Arts \& Humanities in Higher Education 6(2): 169-185.

Kress, Gunther 2005. Gains and losses: New forms of texts, knowledge, and learning. Computers and Composition 22: 5-22.

- 2010. Multimodality: A Social Semiotic Approach to Contemporary Communication. Routledge: London.

Kress, Gunther; Van Leeuwen, Theo 2006[1996]. Reading Images: The Grammar of Visual Design. Routledge: London.

Lamb, Annette 2011. Reading redefined for a transmedia universe. Learning \& Leading with Technology 39(3): 12-17.

Lotman, Juri 1992a. O soderzhanii i strukture ponyatiya «hudozhestvennaya literatura». Izbrannye stat'i $v$ treh tomah. Vol. I. Stat'i po semiotike i topologii kul'tury. Tallinn: Aleksandra, 203-216. [Лотман, Юрий 1992. О содержании и структуре понятия «художественная литература». Избранные статьи в трех томах. Т. I. Статьи по семиотике и топологии культуры. Таллинн: Александра, 203-216].

- 1992b. Semiotika kul'tury i ponyatie teksta. In: Lotman, Juri, Izbrannye stat'i $v$ treh tomah. Vol. I. Stat'i po semiotike i topologii kul'tury. Tallinn: Aleksandra, 129-132. [Семиотика культуры и понятие текста. Избранные статьи в трех томах. T. I. Статьи по семиотике и топологии культуры. Таллинн: Александра, 129-132].

- 1992c. Fenomen kul'tury. In: Lotman, Juri, Izbrannye stat'i $v$ treh tomah. Vol. I. Stat'i po semiotike i topologii kul'tury. Tallinn: Aleksandra, 34-45. [Феномен культуры. Избранные статьи в трех томах. T. I. Статьи по семиотике и топологии культуры. Таллинн: Александра, 34-45].

- 1998. Struktura hudozhestvennogo teksta. In: Lotman, Juri. Ob iskusstve. St. Petersburg: Iskusstvo - SPB, 14-285. [Структура художественного текста. Об искусстве. СПб.: Искусство - СПБ, 14-285].

- 2000. Problema "obucheniya kul'ture" kak tipologicheskaya harakteristika. In: Lotman, Juri, Semiosfera. St. Petersburg: Iskusstvo - SPB, 417-424 [Проблема «обучения культуре» как типологическая характеристика. Семиосфера. СПб.: Искусство - СПБ, 417-424].

- 2001[1990] Universe of the Mind: A Semiotic Theory of Culture. London: I. B. Tauris.

Lotman, Juri M.; Ivanov, Vjacheslav V.; Pjatigorskij, Aleksandr M.; Toporov, Vladimir N.; Uspenskij, Boris A. 1973. Theses on the semiotic study of cultures (as applied to Slavic texts). In: Van der Eng, Jan; Grygar, Mojmír (eds.), Structure of Texts and Semiotics of Culture. The Hague, Paris: Mouton, 1-28.

Mackey, Margaret 1999. Playing in the phase space. Signal 88: 16-33.

- 2001. The survival of engaged reading in the internet age: New media, old media, and the book. Children's Literature in Education 32(3): 167-189.

- 2002. Literacies Across Media: Playing the Text. London: Routledge/Falmer.

Mangen, Anne; Walgermo, Bente R.; Brønnick, Kolbjørn 2013. Reading linear texts on paper versus computer screen: Effects on reading comprehension. International Journal of Educational Research 58: 61-68. 
Manovich, Lev 2001. The Language of New Media. Cambridge, London: MIT Press.

Marcus, Solomon 2015. Cultural heritage: Traps and dramatic choices. Southern Semiotic Review 6(2): 71-84.

Monaco, James 2000. How to Read a Film: The World of Movies, Media, and Multimedia, Language, History, Theory. Oxford: Oxford University Press.

Ojamaa, Maarja 2015. The Transmedial Aspect of Cultural Autocommunication. (Dissertationes Semioticae Universitatis Tartuensis 19.) Tartu: University of Tartu Press.

Ojamaa, Maarja; Peeter Torop 2015. Transmediality of cultural autocommunication. International Journal of Cultural Studies 18(1): 61-78.

Popovič, Anton; Macri, Francis M. 1977. Literary synthesis. Canadian Review of Comparative Literature 4(2): 118-132.

Rockwell, Geoffrey 2002. Gore galore: Literary theory and computer games. Computers and the Humanities 36(3) : 345-358.

Ryan, Marie-Laure 2004. Multivariant narratives. In: Schreibman, Susan; Siemens, Ray; Unsworth, John (eds.), A Companion to Digital Humanities. Oxford: Blackwell, 415-430.

Schreibman, Susan 2002. Computer-mediated texts and textuality: Theory and practice. Computers and the Humanities 36(3): 283-293.

Siegel, Marjorie 1995. More than words: The generative power of transmediation for learning. Canadian Journal of Education 20(4): 455-475.

Sousanis, Nick 2015. Unflattening. Harvard: Harvard University Press.

Toolan, Michael 2010. Foreword. Lost and found in the reading machine. In: Van Peer, Willie; Zyngier, Sonia; Viana, Vander (eds.), Literary Education and Digital Learning: Methods and Technologies for Humanities Studies. New York: Information Science Reference, X-XXIV.

Tymoczko, Maria 2014. Enlarging Translation, Empowering Translators. London, New York: Routledge.

Unsworth, Len 2006. E-literature for Children: Enhancing Digital Literacy Learning. Oxford: Routledge.

Van Leeuwen, Theo 1999. Speech, Music, Sound. London: Macmillan.

Walsh, Maureen 2009. Pedagogic potentials of multimodal literacy. In: Tan Wee Hin, Leo; Subramanian, R. (eds.), Handbook of Research on New Media Literacy at the K-12 Level: Issues and Challenges. Hershey: IGI Global, 32-47.

Warwick, Claire 2004. Print scholarship and digital resources. In: Schreibman, Susan; Siemens, Ray; Unsworth, John (eds.), A Companion to Digital Humanities. Oxford: Blackwell, 366382.

Weldon, John Robert 2012. The effect of digitisation on the novel. The International Journal of the Book 9(4): 57-67.

Winder, William 2004. Robotic poetics. In: Schreibman, Susan; Siemens, Ray; Unsworth, John (eds.), A Companion to Digital Humanities. Oxford: Blackwell, 448-468. 


\section{Переосмысление обучения литературе в цифровую эпоху}

В статье обсуждаются перспективы литературного образования в контексте изменения понятий литературы, чтения и учебы. В то время как повседневные семиотические практики становятся все более дигитальными и мультимодальными, школьное образование все еще сосредоточено в основном на посредничестве оригинальных текстов и их устоявшихся интерпретаций. Менее традиционные источники литературной информации - краткие пересказы, комиксы, мемы, посты социальных сетей составляют значительную часть семиотической среды учащихся. Однако они обычно отклоняются школьным образованием как неверные и несущественные. Семиотика культуры позволяет считать распыленные текстовые версии частью естественной образовательной системы - самой культуры. Целостный подход рекомендуется не только для интеграции повседневных семиотических методов в школьный учебный план, но также и для выявления искомой мультимодальности, трансмедиальности и креативности литературного опыта. В статье исследуются возможные последствия семиотического подхода в трех аспектах литературного образования: мультимодальность и разнородность литературного опыта; влияние цифровых СМИ на привычки восприятия; чтение как творческое создание целого из различных фрагментов. Общая цель - обогатить школьное образование посредством более глубокого понимания литературного опыта и расширения спектра признанных инструментов, форматов и медиумов. Теоретический обзор подкрепляется реальными примерами из школьной практики и развлекательного чтения.

\section{Kirjandushariduse ümbermõtestamine digiajastul}

Artiklis käsitletakse kirjandusõppe perspektiive kirjanduse, lugemise ja õppimise mõistete teisenemise kontekstis. Kui igapäevased semiootilised praktikad on muutumas üha digitaalsemateks ja multimodaalsemateks, keskendub kooliharidus ikka veel suurelt osalt originaaltekstide ning nende väljakujunenud tõlgenduste vahendamisele. Vähemkonventsionaalsed kirjandusteabe allikad - lühikesed ümberjutustused, koomiksid, meemid, sotsiaalmeediapostitused - kipuvad moodustama suure osa õppurite semiootilisest keskkonnast. Koolihariduses jäetakse need siiski tavaliselt kõrvale kui ebaõiged ja ebaolulised. Kultuurisemiootika võimaldab näha pihustunud tekstiversioone osana loomulikust haridussüsteemist - kultuurist enesest. Soovituslik oleks holistlik lähenemine mitte üksnes igapäevaste semiootiliste praktikate lõimimiseks kooli õppekavasse, vaid ka kirjanduskogemuse olemusliku multimodaalsuse, transmediaalsuse ja loomingulisuse esiletoomiseks. Artiklis vaadeldakse semiootika võimalikke järelmeid kolmele kirjandushariduse aspektile, milleks on kirjanduskogemuse multimodaalsus ja heterogeensus; digitaalmeedia mõju tajuharjumustele; lugemine kui erinevatest fragmentidest loomingulise terviku ehitamine. Üldiseks eesmärgiks on rikastada kooliharidust kirjanduskogemuse sügavama mõistmise ning tunnustatavate tööriistade spektri, formaatide ja meediumite laiendamise kaudu. Teoreetilist ülevaadet toetavad elulised näited koolipraktikast ja meelelahutuslikust lugemisest. 